У разі якщо випробування не відбулися, або ніхто з кандидатів їх не витримав або не був затверджений міністром юстиції, останнім пропонувалися імператору для призначення на посаду два претендента, особисто відомих міністру.

У результаті судової реформи 1864 року відбулося організаційне роз'єднання слідства і розшукових підрозділів. Належної законодавчої регламентації в той період організаційний зв'язок попереднього розслідування і розшуку не одержав.

Література:

1. Устав уголовного судопроизводства URL: https://constitution.garant.ru/history/act1600-1918/3137/ (дата звернення 19.10.2020)

DOI https://doi.org/10.30525/978-9934-588-92-1-85

\title{
ЗДІЙСНЕННЯ ЗАТРИМАННЯ У КРИМІНАЛЬНОМУ ПРОВАДЖЕННІ
}

\author{
Гарасимів О. I. \\ кандидат юридичних наук, \\ дочент кафедри кримінального прочесу та криміналістики \\ Львівського державного університету внутрішніх справ \\ Ряшко О. В. \\ кандидат юридичних наук, дочент, \\ доиент кафедри кримінального процесу та криміналістики \\ Львівського державного університету внутрішніх справ \\ м. Львів, Украӥна
}

Проблемою затримання, що негативно впливає на діяльність сторони обвинувачення, є нормативне регулювання умови, відповідно до якої дозволяється застосовувати затримання особи за підозрою у скоєнні лише злочину, санкцією якого визначається покарання у вигляді позбавлення волі, що негативно позначається на діяльності сторони обвинувачення.

Незважаючи на гуманізацію суспільних відносин у сфері кримінального судочинства, а також посилення правових гарантій 
захисту особи, у КПК України знайшов відображення один із найбільш суворих заходів забезпечення кримінального провадження затримання особи за підозрою у вчиненні злочину. У середньому кожен четвертий підозрюваний у вчиненні тяжких та особливо тяжких злочинів затримуються в порядку, передбаченому ст. 208 КПК України підозрюваних у вчиненні тяжких та особливо тяжких злочинів. У таких умовах здійснення посадовою особою правоохоронних органів неправомірного затримання неминуче заподіює істотну шкоду інтересам правосуддя, перешкоджає прийняттю законного й об'єктивного рішення по кримінальному провадженню.

Кримінальне процесуальне законодавство не містить чіткого визначення цілей затримання. Водночас, затримання лише для 3'ясування причетності особи до вчинення злочину й вирішення питання про застосування до неї запобіжного заходу, при відсутності бажання в підозрюваного зникнути, продовжити злочинну діяльність або сховати (знищити) докази, не зовсім виправдане - адже ці питання можливо вирішити й не затримуючи особу, анкетні відомості й місцезнаходження якого відомі органу розслідування. Свобода ж особи повинна обмежуватися виключно тоді, коли без цього неможливо забезпечити виконання поставлених цілей. Саме тому як і будь-який інший запобіжний захід, затримання особи спрямоване на забезпечення виконання підозрюваним, обвинуваченим покладених на нього процесуальних обов'язків, а також запобігання спробам: переховуватися від органів досудового розслідування та/або суду; знищити, сховати або спотворити будь-яку із речей чи документів, які мають істотне значення для встановлення обставин кримінального правопорушення; незаконно впливати на потерпілого, свідка, іншого підозрюваного, обвинуваченого, експерта, спеціаліста у цьому ж кримінальному провадженні; перешкоджати кримінальному провадженню іншим чином; вчинити інше кримінальне правопорушення чи продовжити кримінальне правопорушення, у якому підозрюється, обвинувачується [1, с. 87].

Кримінальне процесуальне затримання $\epsilon$ різновидом саме запобіжного заходу, а не слідчою дією, з приводу чого окремі вчені до цього часу ведуть дискусію, бо вичерпний зміст затримання полягає в запобіганні ухилення підозрюваного, обвинуваченого від слідства i суду, припиненні його злочинної діяльності, запобіганні фальсифікації ним доказів. Разом з тим треба підкреслити, що затримання не може бути віднесено до категорії слідчих дій, оскільки здійснюється, за виключенням його застосування 3 метою забезпечення приводу, до внесення відомостей про правопорушення до Єдиного реєстру 342 
досудових розслідувань, а слідчі дії можуть проводитись лише після цього (можливість проведення у невідкладних випадках слідчого огляду до внесення відомостей до Єдиного реєстру як як екстраординарна дія не спростовує висловлене твердження) [2, с. 11].

Згідно 3 нашим кримінальним процесуальним законодавством затримання як тимчасова ізоляція підозрюваного, обвинуваченого у вчиненні кримінального правопорушення може бути п'яти видів, кожний 3 яких, маючи однаковий процесуальний статус, відрізняється окремою метою та особливостями процедурного характеру [3, 227-229]: а) затримання підозрюваного, обвинуваченого, свідка за ухвалою слідчого судді або суду з метою забезпечення приводу для участі у проведенні процесуальних дій під час досудового розслідування або судового розгляду, якщо їх участь у проведенні цих дій $є$ обов'язковою і вони не з'явились без поважних причин на виклик слідчого або суду (ст.ст. 139, 140 та 187-191 КПК України); б) затримання підозрюваного, обвинуваченого за ухвалою слідчого судді, суду, якщо до одного з них має бути застосований запобіжний захід, не пов'язаний із триманням під вартою (ст.ст. 187, 204 КПК України); в) законне затримання (кожним кожного) в точно встановлених законом випадках без ухвали слідчого судді, суду (ст. 207 КПК України); г) затримання без ухвали слідчого судді, суду уповноваженою службовою особою в точно встановлених законом випадках (ст. 208 КПК України); д) затримання народних депутатів, суддів та інших осіб, визначених ст. 480 КПК України. У всіх випадках затримання особа за чітко виписаною а законі процедурою супроводжується та поміщується до спеціальної установи, ізолятора тимчасового тримання або на гауптвахту (для військовослужбовців).

Існування у кримінальному провадженні різних за функціональною спрямованістю учасників дає можливість виокремити проблеми процесуальних інститутів щодо діяльності органів обвинувачення та стосовно осіб, права і свободи яких обмежуються у кримінальному процесі. Недоліки кримінального процесуального затримання можна поділити на проблеми затримання, що негативно впливають на: 1) діяльність сторони обвинувачення; 2) забезпечення прав і свобод людини. Вказані групи проблем є досить умовними, оскільки перша група дефектів затримання може зумовлювати настання наслідків другої групи недоліків затримання і навпаки. Шляхом виокремлення цих груп проблем затримання автор публікації лише намагався продемонструвати всебічність недосконалості зазначеного заходу забезпечення кримінального провадження [4, с. 99].

Згідно зі ст. 208 КПК, уповноважена службова особа має право без ухвали слідчого судді, суду затримати особу, підозрювану в учиненні 
злочину, за який передбачене покарання у вигляді позбавлення волі, лише у випадках: - якщо цю особу застали під час учинення злочину або замаху на його вчинення (тобто коли особа безпосередньо вчиняла злочин або якщо ця особа 3 прямим умислом здійснила діяння, спрямоване на вчинення злочину, однак не довела його до кінця 3 причин, що не залежали від іiі волі); - якщо безпосередньо після вчинення злочину очевидець, у тому числі потерпілий, або сукупність очевидних ознак на тілі, одязі чи місці події вказують на те, що саме ця особа щойно вчинила злочин; Водночас потребує вирішення питання про затримання особи через деякий час після вчинення злочину без судового дозволу. Як відомо, під час розроблення КПК враховувався світовий досвід забезпечення прав і свобод людини, що стосувалося й проведення затримань у чітко визначених випадках: безпосередньо після скоєння злочину та за наявності обставин, які свідчать про те, що особа щойно скоїла злочин. затримання.

На практиці швидкість дій під час захоплення, з одного боку, прямо впливає на ризик отримати тілесні ушкодження, а з іншого, як було вказано, на позитивний результат для подальшого розслідування кримінального провадження. Однак потреба у раптовості дій не повинна впливати на їх якість: у будь-якій ситуації особи, що здійснюють затримання, повинні зважати на принципи законності й правомірності. Ефективність затримання залежить також від професійних якостей уповноваженої особи або групи осіб. Так, у випадках захоплення групою осіб багато залежить від керівника групи, його вміння організувати та керувати діями інших. Згідно з чинним кримінальним процесуальним законодавством, право застосовувати затримання надано уповноваженій особі (ст. 208 КПК України). Проте не визначено, яка конкретно уповноважена особа: чи оперативний працівник, чи слідчий, чи інший працівник поліції. Однак зрозуміло, що вказані особи фактично керуються однаковими положеннями (згідно з ст. 208 КПК України). Маючи однакові права щодо затримання підозрюваного, ми вважаємо, що в разі виникнення конкретної ситуації варто було б поділити права й обов'язки слідчого та, наприклад, оперативного працівника. Через специфіку діяльності цих практичних працівників формуються різні професійні навики, а також досвід роботи, що безпосередньо впливає на якість і результат дій. Саме тому, погоджуючись із позицією Є. Підусова, вважаємо, що слідчому можна надати право безпосередньо схопити підозрювану особу лише в крайніх випадках [5, с. 119]. 


\title{
Література:
}

1. Фаринник B.I. Затримання особи: проблеми кримінальної процесуальної регламентації та шляхи їх вирішення. Вісник кримінального судочинства. № 2/2015. С. 85-93.

2. Гончаренко В.Г. Правові питання затримання особи в кримінальному провадженні. Часопис Академії адвокатури України том 7 | № 2(23) 2014. С. 11-14.

3. Кримінальне процесуальне право України : навчальний посібник / за редакцією професорів В. Г. Гончаренка та В. А. Колесника. К. : Юстиніан, 2014. 573 с.

4. Лоскутов Т.О. Проблеми затримання особи за підозрою у вчиненні злочину. Науковий вісник Ужгородського національного університету, 2019. С. 97-101.

5. Ангеленюк А.-М. Ю. Затримання підозрюваного уповноваженою особою в провадженнях про незаконний обіг наркотичних засобів i психотропних речовин (процесуальні та криміналістичні аспекти): монографія. Львів: ЛьвДУВС, 2018. 176 с.

DOI https://doi.org/10.30525/978-9934-588-92-1-86

\section{ГІЛЬЙОШ ЯК ЕЛЕМЕНТ ЗАХИСТУ ДОКУМЕНТІВ ТА ЦІННИХ ПАПЕРІВ}

\author{
Гридасова А. Ю. \\ студентка IV курсу \\ Інституту права
}

Київського національного університету імені Тараса Шевченка

м. Київ, Украӥна

3 розвитком поліграфічних технологій підробки стають все складнішими і високотехнологічними. Паралельно з розвитком засобів захисту друкованої продукції удосконалюються методи фальсифікації. Захист документів та цінних паперів від підробок завжди був одним 3 найважливіших завдань у будь-якому суспільстві у всі часи.

Приблизно до кінця XX ст. індустрія фальсифікації технологічно базувалася на найдорожчому й найдосконалішому методі - аналоговому. Тобто підробка створювалася технологічними методами, ідентичними або максимально близькими до методів виготовлення 